\begin{tabular}{c} 
Volume and Issues Obtainable at Center for Sustainability Research and Consultancy \\
Journal of Accounting and Finance in Emerging Economies \\
ISSN: 2519-0318 ISSN (E) 2518-8488 \\
Volume 5: Issue 1 June 2019 \\
CSRᄃ \\
Journal homepage: www.publishing.globalcsrc.org/jafee \\
\hline
\end{tabular}

\title{
Financial Institutions' Inter Mediation and Economic Development in Nigeria
}

${ }^{1}$ Grace Oyeyemi Ogundajo, ${ }^{2}$ Adegbemi Babatunde Onakoya, ${ }^{3}$ Enyi Patrick Enyi, ${ }^{4}$ Tunji T. Siyanbola

${ }^{1}$ Department of Accounting, School of Management Sciences, Babcock University, Ilishan-Remo, Ogun State, Nigeria

${ }^{2}$ Department of Economics, Veronica Adeleke School of Social Sciences, Babcock University, Ilishan-Remo, Ogun State, Nigeria

${ }^{3}$ Department of Accounting, School of Management Sciences, Babcock University, Ilishan-Remo, Ogun State, Nigeria

${ }^{4}$ Department of Accounting, School of Management Sciences, Babcock University, Ilishan-Remo, Ogun State, Nigeria

\begin{tabular}{ll}
\hline \multicolumn{1}{c}{ ARTICLE DETAILS } & ABSTRACT \\
\hline $\begin{array}{l}\text { History } \\
\text { Revised format: May 2019 }\end{array}$ & $\begin{array}{l}\text { Purpose: The This paper examines the effect of intermediation capacity } \\
\text { of the financial institutions on the Nigerian economic development (Real }\end{array}$ \\
& $\begin{array}{l}\text { Gross Domestic Product (RGDP). It is a causal-effect relationship study } \\
\text { which made use of macro data obtained from Central Bank of Nigeria }\end{array}$ \\
\hline Keywords & (CBN) Statistical Bulletin from the period 1981-2016. The result of the \\
Financial Institutions, & Johansen co-integration test and ARDL bound test evidenced that there \\
Intermediation, Economic & exist a long-run relationship between financial institutions activities and \\
Development, Real Gross & real GDP. ARDL regression model showed financial institution activities, \\
Domestic Product & particularly the loans to the private sector significantly impacted on \\
& economic growth both in the short-run and long-run The study also found \\
that bank loans and advances, bank reserves and interest rate had & insignificant negative impact on real GDP while credit to private sector \\
JEL Classification: & significantly affected economic development of Nigeria (RGDP) Thus, \\
economic development of Nigeria is driven by the performance of deposit & money banks and concludes that the performance of deposit money banks \\
has effect on the economic development of Nigeria. The study & recommended that the banking sector should increase lending to the \\
private sector in order to engender economic growth through the \\
enhancement of entrepreneurial development.
\end{tabular}

(C) 2019 The authors, under a Creative Commons Attribution-Non

Commercial 4.0

Corresponding author's email address:

Recommended citation: Ogundajo, G. O., Onakoya, A. B., Enyi, E. P. and Siyanbola, T. T. (2019). Financial Institutions' Inter Mediation and Economic Development in Nigeria. Journal of Accounting and Finance in Emerging Economies, 5 (1), 33-46

DOI: $10.26710 /$ jafee.v5i1.723

\section{Introduction}

The Nigerian economy has since the advent of the oil and gas sector become over dependent on oil-sector of the economy resulting in loss of focus on the other sectors. No sector of the economy in the opinion of Asagunla and Agbede (2018) is positioned to perform effectively without adequate funding which, can only be achieved in an economy with strong financial system. 
Financial intermediaries hold a very important role in the flow of money in the financial world. The assistance of a financial intermediary is needed by companies who want somebody to act as a middle man in raising money from the investors (Siklos, 2001). Meeting up between these two parties are often very difficult without the help of financial intermediaries. Types of financial intermediaries are banks, insurance company, non-banking finance companies, investment brokers, investment bankers and pension funds. Financial intermediation is a process of redistributing the available funds in the economy in maximizing its returns which is the principal role of financial intermediaries (Akinjare, 2016). Indeed, the intermediation role if effectively carried has been established to be a catalyst for economic development of any nation. However, this intermediation role could be plagued with problems such as lack of strong supervision of banks and publicly traded companies leading to collapse, inadequate information for proper efficiency and effectiveness in the economy, fraud and internal control, lack of corporate governance and poor risk management policies and strategy, lack of skilled personnel managerial control, political interference, corruption and nepotism (O'Sullivan \& Sheffrin, 2003).

Financial institutions are responsible for sucking the surpluses in a sector for funding other sector with deficit and this is only attainable if the surplus sectors have confidence in the financial institutions on the security of their savings (Efayena, 2014). Individuals, corporate bodies and government could only entrust their surpluses in the hands of financial institutions of an economy with stable monetary policies and strong capital base.

In recent times, several reforms have been implemented in the Nigerian financial institutions especially in Deposit money banks has undergone several regulatory restructuring in order to effectively carry out their intermediating role in the economy (Paul, 2017). Bank reforms are implemented to substantially increase the capital base of the banks and strengthen the banking system, embrace globalization, improve healthy competition, ensure the safety of depositors' money, position banks to play active developmental roles in the Nigerian economy, exploit economies of scale, adopt advanced technologies, raise efficiency and improve profitability. Ultimately, the goal is to strengthen the intermediation role of banks and to ensure that they are able to perform their developmental role of enhancing economic development, which subsequently leads to improved overall economic performance and societal welfare (O'Sullivan \& Sheffrin, 2003). The 2005 recapitalization in the banking sector was done to; become major players in the sub-regional, regional and global financial markets and compete favourably with international banks (Mike, 2010; Okpara, 2012; Oputu, 2010).

Financial intermediation included the provision of loans and advances. The stringent loan conditions, short-term nature, quality, cost and availability of loanable funds have been the constraints to the expansion and development of businesses including the small and medium scale enterprises in Nigeria. This has led to high rate of unemployment, business failures and crawling growth in the economy over the decades. Nigerian banking sector is devoid of the presence of investment or merchant banks for long-term loans, venture capital for viable businesses proposals. This is may be an indication that the financial sector have not been actively performing the intermediating role, and hence the inadequate growth of the economy (Ogwumike \& Salisu, 2012).

The review of literature on this subject has yielded mixed results hence the need for this paper examined the extent to which money deposit banks have effectively executed its intermediation role towards economic development.

\section{Literature Review}

This consists of theoretical and empirical reviews

\subsection{Theoretical Review}

Schumpeter (1934) in his theory of economic development emphasized the importance of credit as a catalyst and entrepreneur as the prime factor to economic development. He asserted that income distribution and formation of capital in any nation rest on its ability to expand its credit base. Credit capital is inextricably linked with entrepreneurial action. Indeed, the credit mechanisms becomes critical and relevant when its utilization is interconnected with the activity of carrying out 'new combinations' and of moving the production into 'new channels' (Schumpeter $(1934,102)$. In effect, in a capitalist society the entrepreneur is the typical debtor who utilizes the capital in his capacity as an entrepreneur to control and harness concrete goods and diverts the factors of production to new uses, or new direction. 
Financial institutions therefore engender the economic system by circularizing credit in such flow to attain productive advantage. This is achieved by serving as the intercessors between the surplus and deficit sectors of the economy for capital redistribution and creation for entrepreneurial process.

On the contrary, Keynes (1936) theory of economic growth expanded by Robinson (1952) and Chick (1983, 1986) criticized Schumpeter's proposition. They opined that credit could be a constraint to economic growth in a less developed financial system but not applicable in a well-established financial economy. They affirmed that on the one hand, growth is a driver of finance in a highly developed financial system and on the other, financial development germinates as the seed of growth. In effect, there subsist a bi-directional causal relationship between financial development and growth. The intertwined philosophy of financial development and economic growth was stretched by Patrick (1966) as "demand-following" and "supply-leading" chain. While the finance follows the wave of economic growth, financial institutions accumulate the surplus in a system and inject it into viable investments for speedy economic development.

These propositions have been empirically tested in several studies (Menyah, Nazlioglu \& Wolde-Rufael, 2014; Okpara, Onoh, Ogbonna, \& Iheanacho, 2018; Ogwumike \& Salisu, 2012) but with mixed findings. However, the basic proposition of Schumpeter (1936) of the role of credit in entrepreneurial activities as propellant of economic growth remains germane. This is the theory on which this study is predicated. In effect, this study seeks to further investigate the impact of the intermediation role of the banking sector as the major financial institution on the growth of the Nigerian economy.

\subsection{Empirical Review}

Okpara et al., (2018) conducted a co-integrating and VECM analyses to examine the relationship between financial development and economic growth in Nigeria between 1981 and 2014, it was concluded that there is an existence of long run relationship between financial development and economic growth. The study also reported causal-effect relationship exists between capital market and economic growth but no bi-directional association between broad money supply, financing system rating, market capitalization and economic growth.

The Vector Auto-regressive and Granger-causality models deployed by Paul (2017) in examined the effect of financial development and growth of Nigeria economy using asset base, liquid obligations and credit to private sector as measures of financial development. It reported that asset base, liquid obligations and government expenditure negatively impacted on the GDP while credit granted to private sector has significant positive effect on GDP. The result of the bi-directional causal-effect analysis revealed the existence of long run causal-effect relationship between GDP, credit to private sector and government expenditure.

In the same vein, the report of the research carried out by Ndako (2017) using 55 year's data from 1960 to 2014 and the method came to similar conclusions. Similar result was obtained by Shittu (2012) using the same vector error correction model on 41 years data (1970-2010). Shittu concluded that financial intermediation substantially impacted the Nigeria economic growth; while broad money supply exerted significant positive impact on the economy, credit to private sector positively but insignificantly influence GDP in Nigeria. A contrary result was recorded by Adediran (2017) who obtained a negative relationship between loan-deposit ratio and GDP while confirming the existence of a long run relationship exist between financial intermediation and economic growth in Nigeria.

Similar long run investigation was conducted by Biplob and Halder (2018) between financial developments measured as credit to private sector and broad money supply, and economic growth of Bangladesh. The result of the VECM analysis provided evidence of the existence of bilateral granger causality relationship between money supply and GDP. The domestic credit to private sector was however, found to have no influence on the economic growth.

Conversely, the report of Qamruzzaman and Jianguo (2017) on Bangladesh economy proved the existence of both short run and long run bi-directional causal-effect relationship between financial development and economic growth. The finding of Shahbaz, Rehman and Muzaffar (2015) corroborated this report. It discovered that capitalization altered the bidirectional relationship between financial development and economic growth. An Indian investigation carried out by Kaushal and Pathak (2015) provided evidence that financial development did 
not granger-cause economic growth. The reverse is however not the case. Ono (2017) investigated the existence of both the short run and long run relationship between financial innovation and economic growth of Russia using Granger-causality test. The result showed reported that economic growth quickened financial development in the short run. However, in the long run, only bank lending has causal effect on economic growth.

Similar study was conducted by Jalil and Ma (2008) on Pakistan and China economy. It reported significant positive influence of financial development measured as loan-deposit ratio and credit to private sector on the economy development of Pakistan. Similar result was obtained in by the study of Oluitan (2012) on thirty-one African Nations for a time frame of 35years $(1970$ - 2005). It revealed that credit to private sector had significant effect on economic growth of the countries under consideration. In the same vein, the result of the study of Puatwoe and Piabuo (2017) on the Camerounian economy revealed a significant positive relationship between financial development and economic growth.

In the case of China, Jalil and Ma (2008) found that CPS??? had insignificant impact on economic development. Likewise in Zimbabwe; Ndlovu (2013) concluded that financial development has not contributed meaningfully to its economic development. Furthermore, in the Nigerian context, the result of the investigation carried out by Iheanacho (2016) using ARDL model showed that financial institution intermediation exerted insignificant impact on economic growth.

On the reverse, Adu Marbuah and Mensah (2013) concluded that GDP of Ghana is positively impacted by CPS while broad money supply negatively affected the GDP. Likewise, the result of the ARDL and causal-effect analysis carried out by Ofori-Abebrese, Pickson and Diabah (2017) on Ghana economy using 44 years macro data from 1970 to 2013 confirmed this finding.

The investigation on non-oil sector of Saudi Arabian economy reported that the sector was strongly influenced by financial development positively (Samargandi, Fidrmuc and Ghosh, 2013). The correlational analysis on Jordan economy by Al-Qudah (2017) using 84 quarterly data from first quarter of 1993 to second quarter of 2014 concluded that there exists a causal-effect relationship between financial development and GDP on the Jordanian economy. The co-integrating and causal-effect analyses conducted on Indonesian economy by Hafnida (2018) revealed the existence of co-integration between financial development, expenditure by the government, trade openness and economic growth. Indeed, GDP granger caused financial development and trade openness.

The conflicting results obtained from the literature further confirm the need for this study in Nigeria.

\section{Materials and Methods}

\subsection{Research Design and Data Sources}

This is an ex-post causal-effect relationship research, as it considered the past phenomenon. It examined the effect of Deposit Money Banks intermediation on the economy using past occurrences in the current time, and to predict the projected relationship using an established regression model. Macro data obtained from Central Bank of Nigeria (CBN) Statistical Bulletin, 2016 covering a period of 36 years $(1981$ - 2016) was used. The data is adjudged valid because it was a publication of the $\mathrm{CBN}$ and verified by the ruling regulatory bodies. The period of study was chosen conveniently based on availability of information required for the study.

\subsection{Model Specification}

The indicators for measuring the performance of Deposit money banks include commercial bank loans and advances, interest rate, bank reserves and credit to private. The economic growth in Nigeria indicator is the Real GDP. The relationship between the deposit banks and economic development in Nigeria can be represented as such in equation (1):

$\mathrm{RGDP}=\alpha 0+\beta 1 \mathrm{BLAt}+\beta 2 \mathrm{IRt}+\beta 3 \mathrm{BRt}+\beta 4 \mathrm{CPSt}+\mu$

Where:

RGDP $=$ Real Gross Domestic Product

BLA $=$ Bank Loans and Advances

$\mathrm{IR}=$ Interest Rate 
$\mathrm{BR}=$ Bank Reserves

$\mathrm{CPS}=$ Credit to Private Sector

$\mathrm{t}=$ Time

$\alpha 0=$ Intercept while $\beta 1-4=$ Coefficient of BLA, IR, BR CPS; and

$\mu=$ Error Term

\subsection{Estimation Technique}

The preliminary step analysis was conducted to test for the features and stationary of the series. Given that some variables were stationary at level while others were stationary at the first difference, the Auto-Regressive Distributed Lag Models (ARDL) was utilised for the analysis (Cromwell, Labys, Hannan \& Terraza, 1994). ARDL bounds test was also carried out to establish the presence of either co-integration or long run form relationship or both between the Deposit Money banks intermediation and economic growth (RGDP). Prior to the utilization of the ARDL technique, the selection of optimal lag length using Schwarz Bayesian Criterion is also conducted. The Johansen cointegration test is also deployed as preliminary test to determine whether there is even a relationship between the variables at all.

To ensure the exhaustiveness and appropriateness of the model, diagnostic tests were conducted testing the five assumptions underlying the usage of ARDL for the analysis. These are the normality test to check for the stability and consistency of the predictive model using Ramsey Reset Test; the heteroskedasticity, checking for the correlation among the stochastic errors of the model.

\section{Results and Discussion}

4.1 Descriptive Analysis

The main features of the series in the distribution are presented in Table 1.

Table 1: Result of Descriptive Statistics

\begin{tabular}{|l|l|l|l|l|l|}
\hline & RGDP & BLA & BR & CPS & IR \\
\hline Mean & 13.82 & 12.76 & 11.22 & 6.02 & 2.83 \\
\hline Median & 12.88 & 12.77 & 11.38 & 5.97 & 2.86 \\
\hline Maximum & 18.05 & 16.45 & 15.38 & 10.07 & 3.39 \\
\hline Minimum & 12.33 & 9.06 & 6.69 & 2.15 & 2.05 \\
\hline Std. Dev. & 2.08 & 2.61 & 2.79 & 2.62 & 0.29 \\
\hline Skewness & 1.47 & 1 & -0.24 & 0.05 & -0.76 \\
\hline Kurtosis & 3.28 & 1.51 & 1.77 & 1.65 & 3.61 \\
\hline Jarque-Bera & 13.07 & 3.32 & 2.61 & 2.74 & 3.99 \\
\hline Probability & 0.001 & 0.19 & 0.27 & 0.25 & 0.14 \\
\hline Observations & 36 & 36 & 36 & 36 & 36 \\
\hline
\end{tabular}

Source: Researchers' Computations using E-views 9.0 (2019)

Information in Table 1 showed that except for RGDP, the means and median of the variables are approximately equal which, is indicative of a normal distribution. This is corroborated by the in significant variations in the data trend as manifested in the small differences between the minimum and maximum values and the standard variation values.

The series were positively skewed except bank reserves and interest rate. The real GDP and interest rates were leptokurtic because all the Kurtosis values were higher than 3 indicating a higher than normal distribution. The Jacque-Bera statistics is a goodness of normal distribution fit sign-posted the normality of all the variables except RGDP because their Probability of Jacque-Bera statistics were greater than 0.05 significant levels. 


\subsection{Unit Root Test Results}

To ensure that the series are stable over time and deem fit for the regression estimation, unit root tests were conducted at 5\% significance level using Augmented Dickey-Fuller and Phillips-Perron methods and presented in Table 2.

Table 2: Result of Unit root test (ADF and Phillips-Perron Analysis)

\begin{tabular}{|l|l|l|l|l|l|l|l|}
\hline $\begin{array}{l}\text { Variabl } \\
\text { es }\end{array}$ & \multicolumn{2}{|l|}{ ADF } & \multicolumn{3}{l|}{ Phillip-Perron } & $\begin{array}{l}\text { Order of } \\
\text { integration }\end{array}$ \\
\hline & $\begin{array}{l}5 \% \\
\text { critical } \\
\text { Value }\end{array}$ & $\begin{array}{l}\text { ADF at at } \\
\text { level (Prob) }\end{array}$ & $\begin{array}{l}\text { ADF at 1st } \\
\text { difference } \\
\text { (Prob) }\end{array}$ & $\begin{array}{l}5 \% \\
\text { critica } \\
1\end{array}$ & $\begin{array}{l}\text { PP at level } \\
\text { (Prob) }\end{array}$ & $\begin{array}{l}\text { PP at 1st } \\
\text { difference } \\
\text { (Prob) }\end{array}$ & \\
\hline BLA & -1.95 & $1.21(0.94)$ & -2.79 & -1.95 & $3.39(1.00)$ & -2.97 & I(1) \\
\hline BR & -1.95 & $0.96(0.91)$ & -2.60 & -1.95 & $3.31(1.00)$ & -2.66 & I(1) \\
\hline CPS & -1.95 & $7.58(1.00)$ & -3.79 & -1.95 & $8.66(1.00)$ & -3.84 & I(1) \\
\hline IR & -3.57 & -4.80 & $-5.86(0.00)$ & -2.95 & -3.39 & $-9.41(0.00)$ & I(0) \\
\hline RGDP & -1.95 & $0.59(0.84)$ & -5.38 & -1.95 & $0.54(0.83)$ & -5.38 & I (1) \\
\hline
\end{tabular}

Source: Researchers' Computation using E-views 9.0 (2019)

The result of the unit root tests revealed that the series are stable at different order of integration (while interest rate (IR) is stable at level, other variables (BLA, BR, RGDP, CPS) become stable at first difference at 5 per cent significant level). This implies that IR is predictable at level while others are predictable at first difference.

\subsection{Co-Integration Test}

\subsubsection{Johansen co-integration test}

Two types of test were considered under the Johansen test which is Trace test and Max-Eigen statistics. This is presented in Table 3.

Table 3: Result of the Johansen Co-integration Test - Trace and Max-Eigen Statistics

\begin{tabular}{|c|c|c|c|c|c|c|c|}
\hline $\begin{array}{l}\text { Hypothesized } \\
\text { No. of CE (s) }\end{array}$ & Eigenvalue & $\begin{array}{l}\text { Trace } \\
\text { Statistics }\end{array}$ & $\begin{array}{l}0.05 \text { Critical } \\
\text { Value }\end{array}$ & $\begin{array}{l}\text { Prob. } \\
* *\end{array}$ & $\begin{array}{l}\text { Max- } \\
\text { Eigen } \\
\text { Statistics }\end{array}$ & $\begin{array}{l}0.05 \\
\text { Critical } \\
\text { Value }\end{array}$ & $\begin{array}{l}\text { Prob } \\
* *\end{array}$ \\
\hline None $*$ & 0.43 & 18.46 & 4.13 & 0.00 & 18.46 & 4.13 & 0.00 \\
\hline
\end{tabular}

Source: Researchers Computation using E-views 9.0 (2019) **Significant @ 5\%

The result of the co-integration test with the Trace statistics and maximum Eigen statistics being greater than the critical value at 0.05 levels implies that there is co-integration. The series would converge with time (in the long run), even if there are shocks in the short run that would probably affect movement in the individual series.

\subsubsection{Optimal Lag Length Selection:}

The result of the VAR Lag Order Selection Criteria is shown in Table 4

Table 4: Optimal Lag Length Selection

\begin{tabular}{|l|l|l|l|l|l|l|}
\hline Lag & LogL & LR & FPE & AIC & SC & HQ \\
\hline 0 & -354.9914 & NA* & $92^{*}$ & $21.18^{*}$ & $21.40^{*}$ & $21.25^{*}$ \\
\hline 1 & -354.6024 & 0.64 & 96 & 21.21 & 21.48 & 21.30 \\
\hline
\end{tabular}

Source: Researchers Computation using E-views 9.0 (2018)

* indicates lag order selected by the criterion

LR: sequential modified LR test statistic (each test at 5\% level of significance)

FPE: Final Prediction Error

AIC: Akaike Information Criterion

SC: Schwarz Information Criterion 
HQ: Hannnan-Quinn Information Criterion

The result shows that all the criteria suggest the adoption of the zero lag length which means that the impact of the effect of the independent variables could be felt immediately on the dependent variable (Liew, 2004).

\subsubsection{Auto Regressive Distributed Lag Bounds (ARDL) Test}

ARDL bound test was carried out to ascertain the existence of long-run relationship between the independent variables (BLA, BR, CPS, RGDP) and the dependent variable RGDP. Prior to this, the ARDL equation is presented as:

$$
\begin{aligned}
\mathrm{RGDP}=\mathrm{RGDP} & =\alpha_{0}+\sum_{\mathrm{i}=1}^{\mathrm{m}} \beta_{1}^{\mathrm{i}} \Delta \mathrm{BLA}_{\mathrm{t}-1}+\sum_{\mathrm{i}=1}^{\mathrm{m}} \beta_{2}^{\mathrm{i}} \Delta \mathrm{IR}_{\mathrm{t}-1}+\sum_{\mathrm{i}=1}^{\mathrm{m}} \beta_{3}^{\mathrm{i}} \Delta \mathrm{BR}_{\mathrm{t}-1}+\sum_{\mathrm{i}=1}^{\mathrm{m}} \beta_{4}^{\mathrm{i}} \Delta \mathrm{CPS}_{\mathrm{t}-1}+\beta_{5} \mathrm{BLA}_{\mathrm{t}} \\
& +\beta_{6} \mathrm{IR}_{\mathrm{t}}+\beta_{7} \mathrm{BR}_{\mathrm{t}}+\beta_{8} \mathrm{BCPS}_{\mathrm{t}}+\mu
\end{aligned}
$$

The result of the ARDL bound test is presented in Table 5.

Table 5: Result of the ARDL Bound Test

\begin{tabular}{|l|l|l|}
\hline F-Stat =9.17 @ Df =4 & \\
\hline Critical Value Bounds & I0 Bound & I1 Bound \\
\hline$@ 10 \%$ & 2.45 & 3.52 \\
\hline @ 5\% & 2.86 & 4.01 \\
\hline
\end{tabular}

Source: Researchers' Computation using E-views 9.0 (2019)

The value of F-Stat at 4 degree of freedom is 9.17 which is greater than the critical values bound at upper bound (I1) of 4.01 at $5 \%$ and 3.52 at $10 \%$; indicates the existence of long run relationship between the dependent variable and independent variables. Therefore, the long run estimate is examined alongside with the diagnostic tests and the result shown in Table 6.

Table 6: Results of the Long Run Regression Models

\begin{tabular}{|l|l|l|l|l|l|l|l|l|l|}
\hline \multicolumn{1}{|l|}{ Short-Run Form } \\
\hline Variables & Coeff. & Std. & t-Stat & Pro & Variable & Coeff. & Std. & t-Stat & Prob. \\
\hline D(BLA) & -1.76 & 1.71 & -1.03 & 0.31 & BLA & -4.08 & 3.22 & -1.27 & 0.22 \\
\hline D(BR) & -6.13 & 3.23 & -1.89 & 0.07 & BR & -14.24 & 11.83 & -1.20 & 0.24 \\
\hline D(CPS) & 4.07 & 1.51 & 2.69 & 0.01 & CPS & 9.46 & 3.18 & 2.98 & 0.01 \\
\hline D(INTR) & -28.76 & 292.4 & -0.10 & 0.92 & INTR & -66.80 & 677.10 & -0.10 & 0.92 \\
\hline CointEq(- & -0.43 & 0.19 & -2.27 & 0.03 & C & $1,348.96$ & $12,910.0$ & 0.10 & 0.92 \\
\hline Adjusted R-squared & 0.55 & \multicolumn{7}{|l|}{ Adjusted R-squared 0.91} \\
\hline
\end{tabular}

Source: Researchers' Computation using E-views 9.0 (2019)

The results of the ARDL short-run and long run presented revealed that both in the short run and long run, bank loans and advances (DBLA), bank reserve (DBR), and real interest rate (INTR) negatively but insignificantly affect the real gross domestic product (DRGDP). The credit to private sector (DCPS) has significant positive effect on real gross domestic product. DCPS with $\beta=4.07$ in the short run implies that a unit change in DCPS would lead to $4.07 \%$ increase in RGDP, while in the long run the $\beta=9.46$ indicated that a unit change in CPD would resulted to $9.46 \%$ in RGDP.

The probability of F-statistics both in the short run and long run of 0.00 showed that financial institutions intermediation significantly impacted economic development in Nigeria. The coefficient of multiple determination of 0.55 is an indication that $55 \%$ variation in RGDP is caused by the combined variation in DBLA, DBR and INTR in the short run while in the long run the value of adjusted R2 of 0.91 implies that the joint changes in the explanatory variables (BLA, BR and INTR) would lead to 91\% variation in RGDP. Therefore, the 
study concluded that there exist a long-run relationship between financial institutions intermediation and economic growth, particularly the credit to private sector.

\subsection{Post Estimation Tests Results}

The results of four of the post-estimation tests are presented in Table 7

Table 7: Post-estimation Test Results

\begin{tabular}{|l|l|}
\hline Linearity Test & Ramsey RESET Test: F-statistic $=0.198 ;$ Prob. F $(1,29)=0.172$ \\
\hline Heteroskedasticity Test & Breusch-Pagan/Cook-Weisberg Test \\
& ARCH: F-statistic $=2.59$ Prob. F $(1,32)=0.12$ \\
\hline Serial Correlation Test & $\begin{array}{l}\text { Breusch-Godfrey Serial Correlation LM Test: } \\
\text { F-statistic }=2.34 ; \text { Prob. F }(1,28)=0.14\end{array}$ \\
\hline Auto-Correlation Test & Durbin-Watson: 2.44 (short run) 2.21 (long run) \\
\hline
\end{tabular}

Source: Researchers' Computation using E-views 9.0 (2019)

\subsubsection{The Linearity Test}

The linearity assumption of ARDL test was estimated using Ramsey Reset test. The $\rho$-value of the F-stat of 0.17 being greater than the 0.05 significance chosen level implies that the model is correctly specified since the pvalue is more than 0.05. In effect, there exists a linear relationship between the dependent variables and independent variable.

\subsubsection{The Heteroskedasticity Test}

Breusch-Pagan/Cook-Weisberg test was conducted for testing for the consistency of the variations in the residuals of the model over the period " $t$ ". The result with the $\rho$-value of 0.12 being greater than the 0.05 significance chosen level is an reflection of consistencies in the differences of the residuals of the model across the period " $\mathrm{t}$ ". The residuals of the model were stable over time and it is appropriate for estimating the model.

\subsubsection{Serial Correlation Test}

The Breusch-Godfrey Serial Correlation LM Test was carried out to determine the existence of associations among the coefficients of the model and its residuals. Unhealthy association result to the error terms was observed to be smaller than expected and the co-efficient of determination. The statistics derived with $\rho$-value $=$ 0.14 supports the null hypothesis which states that there was no serial correlation among the coefficients of the model and its residuals up to the specified lag order at 5\% significant level.

\subsubsection{Auto-Correlation Test}

The Durbin Watson test was used to detect the presence of autocorrelation at lag 1 in the residuals from a regression analysis. It depicted whether the residuals in the regression analysis model were uncorrelated. The threshold of this test is 2 . The result of 2.21 and 2.42 in the short and long run respectively implies that there was no problem of autocorrelation among the residuals of the regression analysis model.

\subsubsection{Histogram Normality Test}

This test was carried out to check if the model series are normally distributed is presented in Figure 1
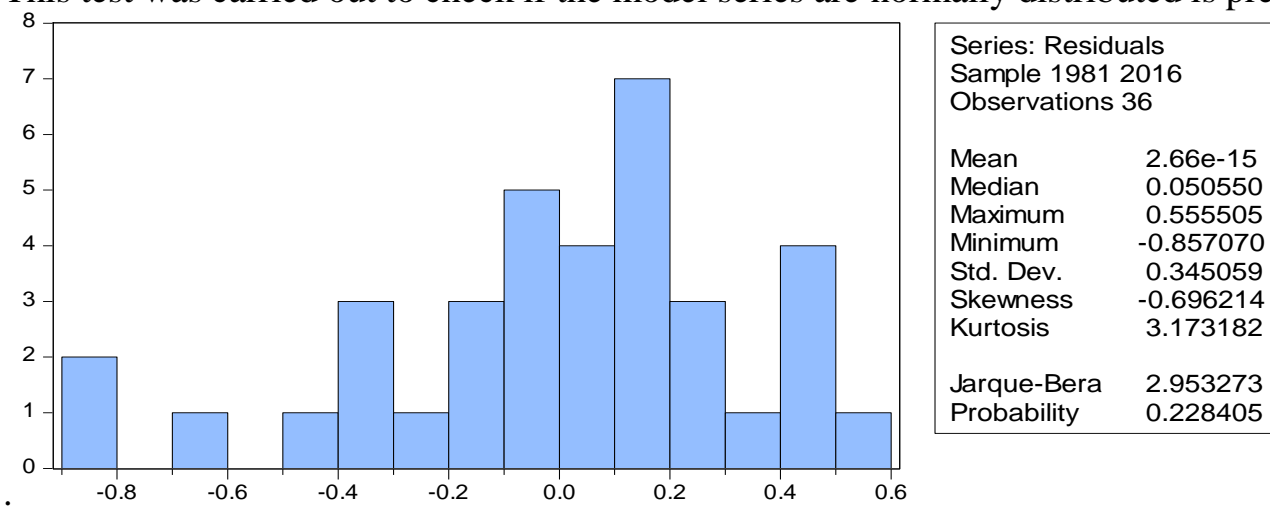

Figure 1: Histogram Normality Test Result 
Source: Researcher's Computation, (2019)

The probability value of the Jarque-Bera test (0.23) which is higher than the critical value of $0.05(5 \%)$ showed that the series in the model are normally distributed. The results of the skewness and the kurtosis also confirmed the normality of the model.

\subsubsection{Stability Test (CUSUM and CUSUM of Squares Residual Test)}

The results of the stability tests of the model are depicted in Figure 2 and Figure 3.

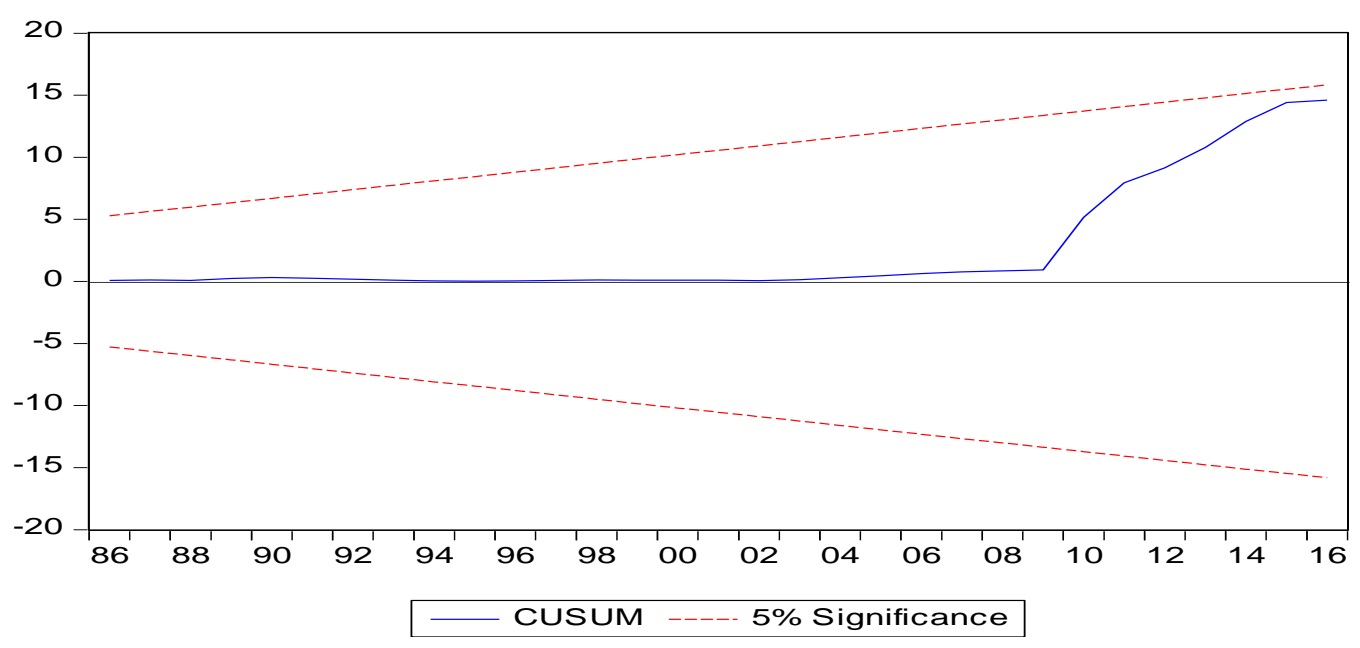

Figure 2: Stability Test (CUSUM Residual Test)

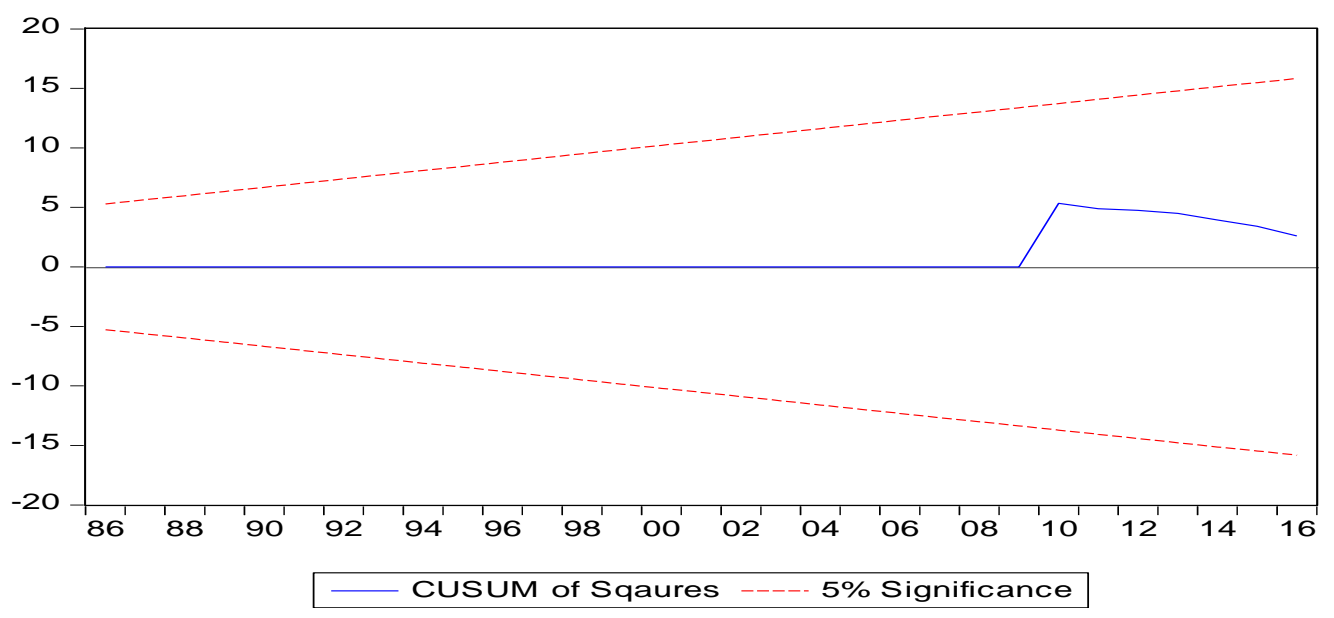

Figure 3: Stability Test (CUSUM of Squares Residual Test)

The CUSUM and CUSUM of Squares test for stability was meant to determine the appropriateness and the stability of the model and therefore suitable for making long- run decision. The figure above plotted within the 5 per cent critical bound (with the lines not crossing one another) implies that the parameters of the model do not suffer from any structural instability over the period of study. The reading of Figures 2 and 3 showed that the model is stable.

\subsection{Discussion of Findings}

This study upholds the proposition of Schumpeter (1936) on which this study is predicated. Credit to the private sector as part of the intermediary functions of the banking is positive and significant in promoting Nigerian economic growth. However, bank loans and advances, bank reserve and interest rate have negative and insignificant impact on the economic growth The result of both the short-run and long-run regression analyses revealed that financial institutions activities as intermediaries significantly influenced the economic growth of Nigeria. 
The result is consistent with those of Adediran (2017), Paul (2017), Puatwoe and Piabuo (2017), Ndako (2017) who also reported that financial development significantly impacted on economic growth and that credit to private sector has material impact on economic growth. Indeed, it upholds the findings of Jalil \& Ma, (2008) that financial development measured as loan-deposit ratio and credit to private sector have significant positive influence the economy development of Pakistan.

This research is contrary to the report of Rehman et al., (2015) on the Bahraini economy which witnessed the absence of relationship between financial development and its economy. It also agreed that financial intermediation substantially impacted the Nigeria economic growth. It however contrasted with Shittu's (2012) work that credit to private sector positively is insignificant in influencing GDP in Nigeria.

The lack of significance of bank loans and advances, bank reserve and interest rate on the economic growth can be ascribed to the constraint bedeviling the banks in its intermediation role with respect to direct intervention funding in the industrial and other sectors. In addition to the consequences of a maturity mismatch, the nearabsence of long-term deposits has continued to constrain the ability of banks to create long-tenured risk assets which are necessary for economic development.

Another limitation is the rising interest rate which has the potential for impairing borrowers' ability to service loans, leading to increased non-performing loans (NPL) and higher loan-loss provisions. Rather than increasing proportionately with the volume of loans from the commercial banks, the growth rate has been at a declining rate. This is consistent with the result of the regression analysis of this study which revealed that bank loans and advances as well as interest negatively influence the real Gross Domestic Product in Nigeria.

Recapitalization of firms in the financial system has been ongoing. The financial systems reforms of 1986 to 1993 led to deregulation of the banking industry; increasing the capitalization level from 5 to 500 million Naira between 1993 and 1998. Between 2000 and 2001, the Central Bank of Nigeria (CBN) raised the capital base of merchant and commercial banks to a uniform level of N1 billion and N2 billion respectively. These, as reported by Bakari (2011) were discovered to be inadequate and led hike to minimum of 25 billion Central Bank of Nigeria $(\mathrm{CBN})$ by December 31, 2005. The resultant consequence was the consolidation of the banking sector in the form of mergers, acquisitions and reduction of eighty nine banks to 22. Despite these series of reforms implemented in terms of increasing the capital and reserve base of the banks to ensure investors security in case of winding up, the result of this study showed that bank reserve was both negative and insignificant in affecting the economic output in Nigeria.

Several other regulatory reforms were initiated by the Central Bank of Nigeria including, new levels of Cash Reserve Requirement (CRR), Monetary Policy Rate (MPR) and the Liquidity Ratio (LR) (CBN, Annual Report, 2012) obviously had no impact according to this study on the intermediating responsibilities of the banking sector.

In all, it is important to emphasize here that the role of credit in Nigerian economic development cannot be over emphasized. The banks have performed creditably well in deposit mobilization, as well as in granting loan and advances, despite various socio-cultural and institutional problems inhibiting financial sector development in Nigeria. This is reflected in the significant positive effect of credit to private sector on the economic growth in Nigeria.

\section{Conclusion}

This study examined the effect of performance deposit money banks on economic development in Nigeria. The only significant independent variable is the credit to private sector (CPS) which has significant positive impact on real gross domestic product. The result showed that in the short and long run, bank loans and advances (DBLA), bank reserve (DBR), and real interest rate (INTR) negatively but insignificantly affect the real gross domestic product (DRGDP). Given the probability of F-statistics values in both the short run and long run, the study confirmed existence of long-run relationship between financial institutions intermediation and economic growth, particularly the credit to private sector.

This study concluded that commercial bank loans and advances, interest rate, bank reserves and credit to private sector have joint statistical significant effect on real GDP. 
The Central Bank of Nigeria should deploy monetary policies capable of enhancing the lending abilities of the banks. Monetary policy should, therefore, emphasize mandatory sectorial allocation of bank credit with appropriate incentives to boost the flow of credit to the economic and manufacturing sectors. The financial sector must equally seek ways of making credit available to the productive sector of the economy.

The government should put in place a revolving intervention fund to meet the long-term funding needs of the manufacturing sector which Deposit Money Banks (DMBs) are unwilling and unable to provide. The funding of specialize financial institutions including the Bank of Industry and Bank of Agriculture for the provision of government-subsidized facilities to the real sector should enhanced. Government fiscal policies should encourage formation of farmer's cooperative societies and micro financing opportunities.

\section{References}

Adediran, O., Ekejiuba, C. P., Matthew, A. O., \& Adegboye, F. B. (2017). Co-integration analysis of financial intermediation and economic growth in Nigeria. Journal of Internet Banking and Commerce, 22(8), 1-12. http://www.icommercecentral.com

Adu, G., Marbuah, G., \& Mensah, J. T. (2013). Financial development and economic growth in Ghana: Does the measure of financial development matter? Review of Development Finance, 3(4), 192-203.

Al-Qudah, A. M. (2017). Financial development and economic growth of Jordan. Research Journal of Finance and Accounting, 7(6), 143-152.

Asagunla, T. M., \& Agbede, M. O. (2018). Oil Revenue and Output Growth in Nigeria. International Journal of Economics and Business Management, 4(6), 65-74. https://www.researchgate.net/publication/330349079

Bakari, A. (2011). The trend and growth implications of bank recapitalization in Nigeria. African Journal of Business Management, 5(14), 5938-5945.

Biplob, N. K., \& Halder, P. (2017). Financial sector development and economic growth: empirical evidence from Bangladesh. Asian Economic and Financial Review, 8(6), 799-814. DOI: 10.18488/journal.aefr.2018.86.799.814. http://www.aessweb.com/

Chick, V. (1983). Macroeconomics After Keynes: A Reconsideration of the General Theory. Oxford: Philip Allan Publisher.

Chick, V. (1986). The evolution of the banking system and the theory of saving, investment and interest. Economies Sciences Series MP, 3. (Reprinted in Philip Arestis and Sheila C. Dow (eds.), the Money, Method and Keynes: Selected Essays, Victoria Chick. 3London: Macmillan, 1992).

Cromwell, J.B., Labys, W.C., Hannan, M.J. \& Terraza, M. (1994). Multivariate Tests For Time Series Models. Thousand Oaks, Carlifornia:SAGE Publications

Efayena, O. (2014). Financial intermediaries and economic growth: The Nigerian evidence. ACTA Universitatis Danubius Economica,10(3), 125-135. http://journals.univ-danubius.ro/index

Hafnida, H. (2018). Relationship between financial development and economic growth: Empirical evidence in Indonesia. International Journal of Economics and Finance, 10(12), 37-42. https://doi.org/10.5539/ijef.v10n12p37

Iheanacho, E. (2016). The impact of financial development on economic growth in Nigeria: An ARDL analysis. Economies, 4(4), 26-36. https://doi.org/10.3390 /economies4040026

Jalil, A., \& Ma, Y. (2008). Financial development and economic growth: Time series evidence from Pakistan and China. Journal of Economic Cooperation, 29(2), 29-68.

Keynes, J. M. (1934). The General Theory of Employment, lnterest and Money. London: Macmillan.

Liew, V.K.S. (2004). Which lag length selection criteria should we employ? Economics Bulletin, 3(33), 1-9.

Menyah, K., Nazlioglu, S., \& Wolde-Rufael, Y. (2014). Financial development, trade openness and economic growth in African countries: New insights from a panel causality approach. Economic Modeling, 37, 386394.

Mike, J. (2010). Banking sector reforms and the manufacturing sector: the manufacturers association of Nigeria perspective. Central Bank of Nigeria Economic and Financial Review, 46(4), 57-65. 
Munyanyi, M. E. (2017). The dynamic relationship between financial development and economic growth: New evidence from Zimbabwe (No. 80401). University Library of Munich, Germany.

Murinde, V. (2012). Financial development and economic growth: Global and African evidence. Journal of African Economies, 21(Supplement 1): i10-i56.

Ndako, U. B. (2017). Financial development, investment and economic growth: Evidence from Nigeria. Journal of Reviews on Global Economics, 6, 33-41. https://doi.org/10.6000/1929-7092.2017.06.03

Ndlovu, G. (2013). Financial sector development and economic growth: Evidence from Zimbabwe. International Journal of Economics and Financial Issues, 3(2), 435-446. (Retrieved from econjournals.com/index.php/ijefi/article/download/401/pdf.)

Nwite, S. C. (2014). Determinants of financial intermediation and its implications on economic growth in Nigeria. British Journal of Marketing Studies, 3(9), 49-56. European Centre for Research Training and Development UK (www.eajournals.org)

Ofori-Abebrese, G., Becker Pickson, R., \& Diabah, B. T. (2017). Financial development and economic growth: Additional evidence from Ghana. Modern Economy, 8, 282-297. https://doi.org/10.4236/me.2017.82020

Ogwumike, F.O., \& Salisu, A. A. (2012). Financial development and economic growth in Nigeria. Journal of Monetary and Economic Integration, 12(2), 91-119. https://www.researchgate.net/publication/315789351

Okpara, G. C. (2012). Soundness and unsoundness of banking sector in Nigeria: A Discriminate Analytical Approach. MPRA Paper No. 36474.

Okpara, G. C., Onoh, A. N., Ogbonna, B. M., \& Iheanacho, E. (2018). Econometrics Analysis of Financial Development and Economic Growth: Evidence from Nigeria. Global Journal of Management and Business Research, 18(2), 1.11. https://globaljournals.org/GJMBR_Volume18/E Journal_GJMBR_(C)_Vol_18_Issue_2.pdf

Oluitan, R. (2012). Financial development and economic growth in Africa: Lessons and prospects. Business and Economic Research, 2(2): 54-67.

Ono, S. (2017). Financial development and economic growth nexus in Russia. Russian Journal of Economics, 3(3), 321-332. https://doi.org/10.1016/j.ruje.2017.09.006

Oputu, E. N. (2010). Banking sector reforms and the industrial sector: the bank of industry experience. Central Bank of Nigeria Economic and Financial Review, 48 (4), 67-76.

O'Sullivan, A. \& Sheffrin, S. M. (2003). Economics: Principles in Action. Upper Saddle River, New Jersey 07458: Pearson Prentice Hall. p. 272

Patrick, H. T. (1966). Financial development and economic growth in underdeveloped countries. Economic Development and Cultural Change, 14(2), 74-89. https://doi.org/10.1086/450153.

Paul, N. (2017). An Examination of the Relationship between Financial Development and Economic Growth in Nigeria: Application of Multivariate VAR Framework. African Research Review (AFRREV), 11(2), 160177. http://dx.doi.org/10.4314/afrrev.v11i2.12

Puatwoe, J. T., \& Piabuo, S. M. (2017). Financial sector development and economic growth: Evidence from Cameroon. Financial Innovation, 3(1), 25. https://doi.org/10.1186/s40854-017-0073-x

Qamruzzaman, M., \& Jianguo, W. (2017). Financial innovation and economic growth in Bangladesh. Financial Innovation, 3(19), 1-24. https://doi.org/10.1186/S40854-017-0070-0

Rehman, M. Z., Ali, N., \& Nasir, N. M. (2015). Financial development, savings and economic growth: Evidence from Bahrain using VAR. International Journal of Financial Research, 6(2), 112-123. DOI: https://doi.org/10.5430/ijfr.v6n2p112.

Robinson, J. (1952). The Generalization of the General Theory, the Rate of Interest and Other Essays. London: Macmillan, 67-142.

Samargandi, N., Fidrmuc, J., \& Ghosh, S. (2013). Financial development and economic growth in an oil-rich economy: The case of Saudi Arabia. Economics and Finance Working Paper No. 13-12.

Schumpeter, J. A. (1934). The Theory of Economic Development: An Inquiry into Profits, Capital, Credit, Interest, and the Business Cycle. University of Illinois at Urbana-Champaign's Academy for Entrepreneurial Leadership Historical Research Reference in Entrepreneurship. 
https://ssrn.com/abstract=1496199.

Shahbaz, M., I.U. Rehman and A.T. Muzaffar, (2015). Re-visiting financial development and economic growth nexus: The role of capitalization in Bangladesh. South African Journal of Economics, 83(3), 452-471. https://mpra.ub.uni-muenchen.de/57500/

Shittu, A. I. (2012). Financial intermediation and economic growth in Nigeria. British Journal of Arts and Social Science, $\quad 4(2), \quad$ 164-179. $\quad$ https://www.researchgate.net/publication/299393310 http://www.bjournal.co.uk/BJASS.aspx

Siklos, P. (2001). Money, Banking, and Financial Institutions: Canada in the Global Environment. Toronto: McGraw-Hill Ryerson. p. 35 
